\title{
Importance of Goat Milk
}

\section{REWATI RAMAN BHATTARAI*}

\author{
Central Campus of Technology, Hattisar, Dharan
}

Goats are important component of livestock industry having adaptability to harsh climates which make them suitable for landless and marginal farmers. The contribution of goats in supplying milk and milk products is high and it has significant role in rural economy and health. Goat milk contains higher amount of $\mathrm{Ca}, \mathrm{Mg}$ and P than cow and human milk. Medium Chain Triglycerides (MCT) which are more in goat milk have been recognized as unique lipid with unique health benefits. The soft curd of goat milk may be an advantage for adult humans suffering from gastrointestinal disturbances and ulcers. Goat milk is recommended for infants, old and convalescent people. The consumer acceptance of goat milk and its products is reported to be excellent. Goat cheese production in Nepal is coming up in a big way which will prove to be a boon to Nepalese cheese industry. Despite this fact, goat has remained neglected in research and development. Universally recognized as 'poor man's cow', goat now has to be fully exploited to get maximum benefits, particularly meat, milk and milk products having medicinal values.

Keywords: Goat milk, Medicinal value, Marketing, Nepal

\section{Introduction}

Due to rapidly increasing human population, the demand for milk and milk products is on the rise in the tropical developing countries. The increased demand can be met by increasing ruminant livestock population as suggested by Devendra and McLeroy (1982). The contribution of small ruminants in general and goats in particular in meeting this demand will be very high. Goats are important milk producers in several parts of the tropics and contribute significantly to human nutrition in many developing countries (Devendra, 1999). A goat is universally called as "Poor man's cow" (Iqbal et al., 2008). Developing countries raise 775 million of the 809 million goats in the world and 86 percent of them are in low-income countries with a food deficit. Sixty-five per cent of the global goat population is maintained in the developing countries of Asia and 29 percent in Africa (Singh et al., 2006). Goat's population is increasing in Nepal each year and according to FAOSTAT, 2010 it is around 8.8 million. These statistics are a strong indication of the importance of goats in the livelihoods of people in developing and under-developed countries, especially in Asia (Singh et al., 2006). Asia alone produces about $80 \%$ goat milk (Iqbal et al., 2008). In this regard main countries include India, China, Bangladesh, Iran, Pakistan and Turkey (Khan et al., 2003).

\section{Why goat?}

In Nepal, the goats are an important livestock species uniquely adapted to the temperate environment. Goats can survive under environmental conditions that are difficult for other domestic livestock species. According to Devendra (1999), goats have small land and initial investment requirements, and their adaptability to harsh climates makes them suitable for landless and marginal farmers. Goat milk is very nutritious and is an acceptable food in several parts of the tropics (Devendra, 1999). Daily milk yield varies from $0.9 \mathrm{~L}$ to $4.5 \mathrm{~L}$ as reported by different researchers (Iqbal et al., 2008). Goats are profilic breeders and achieve sexual maturity at an early age of 10-12 months; gestation period in goats is short and it starts giving milk at the age of 16-17 months (Mangurkar, 2007).

\footnotetext{
*Corresponding author, E-mail: noble_rewinem1@yahoo.com
}

\section{Composition of goat milk}

Compositions of goat milk vary with diet, breed, individuals, parity, season, feeding, management, environmental conditions, locality, stage of lactation, and health status of the udder (Park et al., 2007) which also affects taste of goat milk. Comparison between composition of goat milk with of cow and human milk is given in Table 1.

\section{General characteristics of goat milk}

Goat milk contains 3.8\% fat, 3.4\% protein, $4.1 \%$ lactose, $0.8 \%$ ash, $8.9 \%$ SNF (Park et al., 2007) and $87 \%$ water (Iqbal et al., 2008). Goat milk differs from cow or human milk in having better digestibility, alkalinity, buffering capacity and certain therapeutic values in medicine and human nutrition (Haenlein and Caccese, 1984; Park and Chukwu, 1989; Park, 1994). Density of goat milk is comparable to that of cow milk, while it has higher specific gravity, viscosity, titratable acidity, but lower refractive index and freezing point than cow milk (Parkash and Jenness, 1968; Haenlein and Wendorff, 2006). The freezing point of goat milk is about $-0.580^{\circ} \mathrm{C}$, viscosity $13.4 \mathrm{mP}$ at $27^{\circ} \mathrm{C}$, titrable acidity as lactic acid ranges from 0.11 to 0.18 per cent (Roy and Vadodaria, 2006). Surface tension of goat milk is within the range of cow milk (Ju'arez and Ramos, 1986). The mean $\mathrm{pH}$ value ranges from 6.5 to 6.9. The curd tension of goat milk is much lower than that of cow milk. The average value with pepsin-HCL test was 36 (Roy and Vadodaria, 2006).

\section{Physico-chemical properties of goat milk constituents} Lipids in goat milk have higher physical characteristics, than in cow milk, but there are variations between different reports (Anifantakis, 1986; Park, 2006a). Lipids in goat milk have generally higher physical characteristics than in cow milk (Anifantakis, 1986; Park, 2006a). The unsaponifiable matter of milk fat and acid values are not different between goat and cow milk, but goat milk has lower iodine values, which reflects its greater amount on lower and unsaturated fatty acids (Park, 2006a).

Cow milk has a higher saponification value and slightly greater refractive index than goat milk, which relates to the 
Table 1. Composition of goat milk in comparison with cow and human milk

\begin{tabular}{|c|c|c|c|}
\hline \multirow[t]{2}{*}{ Particulars } & \multicolumn{3}{|c|}{ Per 100 gram } \\
\hline & Goat & Cow & Human \\
\hline Total solid (\%) & 12.97 & 12.01 & 12.5 \\
\hline Energy kilo calorie & 69 & 61 & 70 \\
\hline Protein $(\%)$ & 3.56 & 3.29 & 1.03 \\
\hline Lipid (\%) & 4.14 & 3.34 & 4.38 \\
\hline Carbohydrates (\%) & 4.45 & 4.6 & 6.89 \\
\hline Ash $(\%)$ & 0.82 & 0.72 & 0.2 \\
\hline Calcium (mg) & 134 & 119 & 32 \\
\hline Iron (mg) & 0.05 & 0.05 & 0.03 \\
\hline Magnesium (mg) & 14 & 13 & 3 \\
\hline Phosphorus (mg) & 111 & 93 & 14 \\
\hline Potassium (mg) & 204 & 152 & 51 \\
\hline Sodium (mg) & 50 & 49 & 17 \\
\hline Zinc (mg) & 0.3 & 0.38 & 0.17 \\
\hline Ascorbic acid (mg) & 1.29 & 0.94 & 5 \\
\hline Thiamin (mcg) & 40 & 40 & 20 \\
\hline Riboflavin (mg) & 0.138 & 0.162 & 0.036 \\
\hline Niacin (mg) & 0.277 & 0.084 & 0.177 \\
\hline Panthothenic acid (mg) & 0.13 & 0.314 & 0.223 \\
\hline Vitamin $B_{6}(\mathrm{mcg})$ & 60 & 60 & 10 \\
\hline Folacin (mcg) & 1 & 6 & 5 \\
\hline Vitamin $B_{12}(\mathrm{mcg})$ & 0.065 & 0.0357 & 0.045 \\
\hline Vitamin A RE (mcg) & 44 & 52 & 58 \\
\hline Vitamin D (mcg) & 0.11 & 0.03 & 0.04 \\
\hline Vitamin E (mg) & 0.03 & 0.09 & 0.34 \\
\hline Vitamin C (mg) & 1 & 1 & 4 \\
\hline
\end{tabular}

Source: Haenlein, (2001)

longer carbon chains and saturation of the fatty acids (Park, 2006a). Goat milk may have lower Reichert Meissl and higher Polenske values than cow milk, suggesting that goat milk fat contains less soluble and more insoluble volatile fatty acids than cow milk fat (Park, 2006a).

Remeuf and Lenoir (1986) reported that the relative proportions of the major casein components of goat milk are quite different from those in cow milk. Goat milk contains less $\alpha_{\mathrm{s}}$-casein, and often has more $\alpha_{\mathrm{s} 2}$ than $\alpha_{\mathrm{s} 1}$-casein. The latter is present in highly variable amounts depending on individual goats (Mora-Gutierrez et al., 1991). Proportions of $\kappa$-casein and especially $\beta$-casein are higher in goat than in cow milk. Casein contents in goat milk range from 16 to $26 \mathrm{~g} / \mathrm{L}$, the proportions of NPN of the total nitrogen content are between
$3 \%$ and $13 \%$, the ionized calcium levels between 0.07 and $0.19 \mathrm{~g} / \mathrm{L}$, the total inorganic phosphorus between 0.45 and $1.0 \mathrm{~g} / \mathrm{L}$ (Remeuf and Lenoir, 1986), depending on individuals, lactation period, and sample differences (Parkash and Jenness, 1968). The relative compositions of essential amino acids are given in Table 2. The vitamins in goat milk are comparable with those of cow and human milk (Roy and Vadodaria, 2006). The mineral contents of goat milk have already been presented in Table 1. Goat milk contains more calcium, phosphorus and potassium than cow and human milk.

\section{Dietary and medical significance of goat milk}

Goat milk is adequate for human infant in vitamin A and niacin and supplies generous excesses of thiamin, riboflavin and pantotheanate (Jenness, 1980; Haenlein, 2004). It is, however, 
Table 2. Relative composition of essential amino acids in goat and cow milk taking human milk as standard

\begin{tabular}{lcc}
\hline Particulars & Goat & Cow \\
\hline Arginine & 277 & 277 \\
Histidine & 387 & 387 \\
Isoleucine & 370 & 355 \\
Leucine & 330 & 339 \\
Lysine & 426 & 384 \\
Methionine & 381 & 395 \\
Phenylalanine & 337 & 346 \\
Threonine & 354 & 324 \\
Tryptophan & 259 & 270 \\
Valine & 381 & 349 \\
\hline
\end{tabular}

Source: Haenlein, (2001)

deficient in vitamins $\mathrm{C}, \mathrm{D}, \mathrm{B}_{12}$, pyridoxine and folic acid (Park, 1994). Thus, when used for infant feeding, goat milk must be corrected by appropriate fortification.

One of the most important contributions of goat milk to human nutrition is the calcium and phosphate that it supplies. Goat milk contains about $1.2 \mathrm{~g}$ calcium and $1 \mathrm{~g}$ phosphate per litre; these concentrations are similar to those in cow milk (Jenness, 1980). Human milk contains much less of these minerals with only one-fourth as much calcium and one-sixth as much phosphate. Thus goat milk provides a great excess of $\mathrm{Ca}$ and $P$ in relation to energy to human infant, both calcium and phosphorus of goat milk are absorbed by the human infant (Jenness, 1980).

The soft curd of goat milk may be an advantage for adult humans suffering from gastrointestinal disturbances and ulcers (Haenlein, 2004). High buffering capacity of goat milk appears to be useful for treatment of gastric ulcers (Park, 1994). Goat milk has been recommended as a substitute for patients allergic to cow milk. Between 40-100\% of patients allergic to cow milk proteins tolerate goat milk (Park, 1994). Medium chain length fatty acid or Medium Chain Triglycerides (MCT) which are more in goat milk have been recognized as unique lipid with unique health benefits in mal-absorption syndromes, chyluria, steatorrhea, hyperlipoproteinnemia, and in cases of intestinal resection, coronary bypass, premature infant feeding, childhood epilepsy, cystic fibrosis and gallstones. MCT also inhibits or limits cholesterol deposition, dissolve cholesterol gallstones and contributes to normal growth of infants (Roy and Vadodaria, 2006).

\section{Goat milk and milk products}

Traditionally, goat milk is produced in small farms. Fresh goat milk is sold as pasteurized milk and in variety of packaging in super market chains and health food shops in many western countries. In fact, fresh milk obtained under sanitary conditions from properly fed and managed healthy goats is free from objectionable flavour and odour (Roy and Vadodaria, 2006). The consumer acceptance of goat milk and its products is reported to be excellent. Some of these as described by Roy and Vadodaria, (2006) are discussed as below:

Special beverage- The goat milk standardized to $2 \%$ fat and $10.5 \%$ SNF was fortified with Vitamin A and D to label it as protein fortified low fat goat milk.

Khoa mawa- Mawa made from goat milk is sticky, no release of fat occurs during preparation, yellowish colored with moist surface, hard body and smooth texture.

Paneer-Good quality paneer free from goaty odour and flavor can be prepared.

Chhana- Good quality chhana has been prepared from goat milk which has been used for preparing Sandesh and Rasagolla.

Ice-cream- A premium quality ice-cream can be prepared using goat milk.

Infant Foods- In USA and South Africa, goat milk is sold in evaporated or spray dried form for pediatric use.

Yoghurt- Literature says that goat milk yoghurt is available on most supermarket shelves.

The characteristic goaty flavour is completely masked in goat milk yoghurt. Another positive aspect is that it does not show 'wheying off' at $4{ }^{\circ} \mathrm{C}$ storage as in case of unhomogenized cow milk yoghurt.

Ghee- Goat milk, due to its relatively small fat globules pose a problem during separation and its typical flavour, for ghee manufacture. In addition, ghee from goat milk is greasy. Therefore, blending of goat milk with buffalo milk in 1:1 ratio yields good quality ghee.

Cheese-Soft and semi hard varieties of cheeses are made from goat milk. In European countries, these cheeses are marketed as 'Premium Cheese'. According to Pal et al., 2011, Greece and France have the largest goat milk cheese production. In India, goat milk has been used for making hard cheese. Attempts have also been made to manufacture Mozzarella cheese from blends of cow, goat and/or buffalo milk.

\section{Nepalese scenario of goat cheese making}

Goat milk is the proprietary item for a few varieties of soft, hard and semi-hard cheeses. Cheese production in 
Nepal is coming up in a big way. Recently, Jamunapari and Saanen goat milk has been used for making soft and hard cheeses in the country following the path of France. France contributed technology and other support for initiation of goat milk production in Nepal. The ripened goat cheeses have characteristic piquant and peppery sharp flavor (Personal Communication, 2012).

\section{Functional benefits of goat cheese}

Goat cheese, like goat milk, is easier on the human digestive system and lower in calories, cholesterol and fat than its bovine counterpart. In addition, goat milk cheese is rich in calcium, protein, vitamin A, vitamin $\mathrm{K}$, phosphorus, niacin and thiamin. The fats found in goat milk products are high in middle chain fatty acids, which are easier for the body to process than those found in cow's milk (Anon., 2012).

\section{Marketing potential of goat milk and cheese}

Medicinal value of goat milk has been documented in Nepalese Ayurveda (Nepalese Traditional Medicine) (Bajracharya et al., 2010), Indian Ayurveda and Bhavprakash and goat milk was recommended as an effective dietary item for the patients suffering from tuberculosis, dysentery, cough and cold and certain gynaecological disorders (Pal et al., 2011). In recent years, there has been an increased interest for goat milk production and conversion to value added products. There is increasing demand for organic and healthy dairy food worldwide including Nepal. The marketing value of such products in developed countries is estimated around US $\$ 14180$ million and it is rapidly growing on an average of $10-12 \%$ annually. In some countries, the growth is expected to cross more than $30 \%$ (Rathinam, 2005). This trend of consumer interest in goat cheese in Nepal is increasing and the present demand of goat cheese is not fulfilled by supply (Personal Communication, 2012). Mostly cheese is consumed in pizza parlours and fast food chains and to meet the demand, industrial production of cheese is continuously growing (Bhattarai and Acharya, 2010). Goat milk can be used as a major raw material for development of soft, semi soft and hard cheeses in the country which will prove to be a boon to Nepalese cheese industry.

\section{Conclusion}

In conclusion, it can be said that the contribution of goats in supplying milk and milk products is high and it has significant role in rural economy and health especially for developing countries like Nepal. Despite this fact, goat has remained neglected in research and development. Universally recognized as 'poor man's cow', goat has to be fully exploited to get maximum benefits, particularly meat, milk and milk products having medicinal values. This could be a greatest advantage for industrialization of a country.

\section{References}

Anifantakis E. M. (1986). Comparison of the physico-chemical properties of ewe's and cow's milk. In: International Dairy Federation (Ed.), Proceedings of the IDF Seminar Production and Utilization of Ewe's and Goat's Milk, Bulletin No. 202. Athens, Greece, pp. 42-53.

Anonymous, (2012). Health Benefits of Goat Cheese. Available at: http://www.redwoodhill.com/artisan-cheese/ health-benefits-of-goat-cheese

Bajracharya M. B., Tillotson A. and Caldecott T. (2010). Review of Ayurvedic Medicines - Formulas. Available at: http://www.ayurvedainnepal.com/medicine/reviewof-ayurvedic-medicines-formulas/

Bhattarai R. R. and Acharya P. P. (2010). Preparation and Quality Evaluation of Mozzarella Cheese from Different Milk Sources. J. Food Sci. \& Technol. Nepal, 6: 94-101.

Devendra C. (1999). Goats: challenges for increased productivity and improved livelihoods. Outlook on Agriculture, 28: 215-226.

Devendra C. and McLeroy G. B. (1982). Goats and sheep reproduction in the tropics. ELBS edition. Longman. Singapore. pp. 78 .

FAOSTAT (2010). Available at: /http://faostat.fao.org/ site/573/default.aspx\#ancor

Haenlein G. F. W. (2001). The Nutritive Value of Sheep Milk, Inter. J. Anim. Sci. 160(2): 253-268

Haenlein G. F. W. (2004). Goat milk in human nutrition. Small Rumin. Res. 51: 154-163.

Haenlein G. F. W. and Caccese R. (1984). Goat milk versus cow milk. In: Haenlein, G.F.W., Ace, D.L. (Eds.), Extension Goat Handbook. USDA Publ., Washington, DC, p. 1, E-1.

Haenlein G. F. W. and Wendorff W. L. (2006). Sheep milkproduction and utilization of sheep milk. In: Park, Y.W., Haenlein, G.F.W. (Eds.), Handbook of Milk of NonBovine Mammals. Blackwell Publishing Professional, Oxford, UK, and Ames, Iowa, USA, pp. 137- 194.

Iqbal A., Khan B.B., Tariq M. and Mirza M.A. (2008). Goat-A Potential Dairy Animal: Present and Future Prospects. Pak. J. Agri. Sci., 45(2): 227-230.

Jenness R. (1980). Composition and characteristics of goat milk: Review. J. Dairy Sci., 63: 1605-1630. 
Ju'arez M. and Ramos M. (1986). Physico-chemical characteristics of goat milk as distinct from those of cow milk. In: International Dairy Federation (Ed.), Proceedings of the IDF Seminar Production and Utilization of Ewe's and Goat's Milk, Bulletin No. 202. Athens, Greece, pp. $54-67$.

Khan B. B., Iqbal A. and M. L. Mustafa (2003). Sheep and Goat Production. Department of Livestock Management. University of Agriculture, Faisalabad.

Mangurkar B. R. (2007). Sustainable Goat Production in SemiArid Areas in India. Indian Dairyman, 59 (11): 51-57.

Mora-Gutierrez A., Kumosinski T.F. and Farrell Jr. H.M. (1991). Quantification of $\alpha \mathrm{s}_{1}$-casein in goat milk from French-Alpine and Anglo-Nubian breeds using reversedphase HPLC. J. Dairy Sci., 74: 3303-3307.

Pal U. K., Mandal P. K., Rao V. K. and Das C. D. (2011). Quality and Utility of Goat Milk with Special Reference to India: An Overview. Asian J. of Animal Sci., 5: 56-63.

Park Y. W. (1994). Hypo-allergenic and therapeutic significance of goat milk. Small Rumin. Res. 14: 151-161.

Park Y. W. (2006a). Goat milk-chemistry and nutrition. In: Park,Y.W., Haenlein, G.F.W. (Eds.), Handbook of Milk of Non-bovine Mammals. Blackwell Publishing Professional, Oxford, UK/Ames, Iowa, pp. 34-58.
Park Y. W. and Chukwu H. I. (1989). Trace mineral concentrations in goat milk from French-Alpine and Anglo-Nubian breeds during the first 5 months of lactation. J. Food Compos. Anal. 2:161-169.

Park Y.W., Ju'arez M., Ramos M. and Haenlein G. F. W. (2007). Physico-chemical characteristics of goat and sheep milk. Small Rumin. Res. 68: 88-113.

Parkash S. and Jenness R. (1968). The composition and characteristics of goat milk: Review. Dairy Sci. Abstr. 30: $67-72$.

Personal communication (2012). Subhash Osti. RFTQC, Hetauda. 9845104372.

Rathinam R. (2005). Organic and health dairy foods for emerging market. Indian Dairyman, 57: 76-81.

Remeuf F. and Lenoir J. (1986). Relationship between the physico-chemical characteristics of goat's milk and its rennetability. Intl. Dairy Bull., 202, 68.

Roy S. K. and Vadodaria V. P. (2006). Goat Milk and Its Importance. Indian Dairyman, 58 (3): 65-69.

Singh S. K., Singh M. K. and Singh N. P. (2006). Role of goats in sustainable rural livelihoods in India. In "Goats - Undervalued Assets in Asia". Proceedings of the AphcaIlri Regional Workshop on Goat Production Systemsand Markets. Luang Prabang, Lao PDR, 24 - 25 October 2006. 